\title{
WOMEN IN REPRODUCTIVE SCIENCE Discovering science and the ovary: a career of joy
}

\author{
JoAnne S Richards \\ Department of Molecular and Cellular Biology, Dan L Duncan Comprehensive Cancer Center, Baylor College of \\ Medicine, Houston, Texas, USA \\ Correspondence should be addressed to J S Richards; Email: joanner@bcm.edu
}

This paper forms part of special issue on Women in Reproductive Science. The guest editor for this section was Professor Marilyn Renfree, Ian Potter Chair of Zoology, School of BioSciences, The University of Melbourne, Victoria, Australia.

\begin{abstract}
My career has been about discovering science and learning the joys of the discovery process itself. It has been a challenging but rewarding process filled with many exciting moments and wonderful colleagues and students. Although I went to college to become a French major, I ultimately stumbled into research while pursuing a Masters Degree in teaching. Thus, my research career began in graduate school where I was studying NAD kinase in the ovary as a possible regulator of steroidogenesis, a big issue in the late $1960 \mathrm{~s}$. After a short excursion of teaching in North Dakota, I became a postdoctoral fellow at the University of Michigan, where radioimmuno assays and radio receptor assays had just come on the scene and were transforming endocrinology from laborious bioassays to quantitative science and of course these assays related to the ovary. From there I went to Baylor College of Medicine, a mecca of molecular biology, cloning genes and generating mouse models. It has been a fascinating and joyous journey.

Reproduction (2019) 157 F69-F80
\end{abstract}

\section{Early days, growing up}

My career in science developed by default and a whole lot of luck. I was born in Exeter and grew up in Durham, New Hampshire. My father was the only person in his family to go to college, all others worked in the shoe mills. My mother was a graduate of physiology at Mount Holyoke College; somehow they met at a gas station in $\mathrm{NH}$ where my Dad was pumping gas. They married and eventually, after starting as an English major, my Dad became a professor of geology at the University of New Hampshire in Durham. My father's expertise in geology meant that he surveyed prospective sites for mica mines in Vermont during WWII; I was a WWII baby.

I went to Oyster River High School in Durham; I loved Latin and French. Chemistry and Biology were just OK. My passions were horses and figure skating. I took riding lessons and competed; blue ribbons were the goal. I took figure skating lessons in Durham from talented UNH graduate students on an outdoor rink in the winter and in Boston at the Boston Figure Skating Club from September to May. My dear mother drove me to Boston on Friday afternoons and I would study along the way leaving her to make the 3 -h round trip essentially by herself. I passed some of the required compulsory figure skating tests but never had the time or the temperament (too shy) to excel in free style. I dearly loved the sport but was clearly not bound for the Olympics!
Most memorable of all were the many summers my family spent on my grandparents' farm in $\mathrm{NH}$ where we had horses and farmed the old-fashioned way (Fig. 1). We made hay with a horse-drawn wooden hay wagon, using old-fashioned hay forks and pitched loose hay into the mow of an 18th century barn constructed with huge wooden beams and wooden pegs. There were no nails! My mother's stern discipline and demand for excellence ensured that the hay was made to perfection. Her barn would not burn down with hay that was not dry! When we were not haying or weeding the vegetable garden and if the day started with clear blue skies and sunshine (rare in $\mathrm{NH}$ ), we would head for the mountains to enjoy a vigorous hike or to the seashore ( $\mathrm{NH}$ has all of 11 miles!) for a swim (dip!) in the cold Atlantic. I had a wonderful life growing up! And I still treasure all the memories. Luckily for me, I inherited the old farm and still have Mother's helpers to run it! I just don't get there very often. A brief personal profile along with a list of some of my published research is presented in Box 1.

\section{College days, more growing up}

From this wonderful, idyllic life surrounded by the lakes, mountains and the seashore of New Hampshire, I went off to Oberlin College (Ohio) in the middle of a corn field to become a French major. I had been inspired by 


\section{Box 1: Prof. JoAnne S Richards, PhD}

I am currently a professor in the Department of Molecular and Cellular Biology (MCB) and the Dan L Duncan Cancer Center at Baylor College of Medicine in Houston, Texas. I have been in MCB Department since 1981 and have been honored to have many wonderful faculty colleagues, postdoctoral fellows and graduate students as well as visiting faculty such as Dr Larry Espey from Trinity University in San Antonio, Texas and Dr. Masayuki Shimada, Hiroshima University, Japan. Collectively, we have worked to understand the molecular and cellular mechanisms that regulate ovarian follicular development, ovulation and ovarian cancer. There have been many exciting moments in my career but perhaps the most memorable was discovering a second antigenic form of cyclooxygenase, now known as cyclooxygenase 2 (COX2) or prostaglandin synthase 2 (PTGS2). It was memorable because it was so unexpected and because it took us so long to figure it out. But once we had the right reagents the story unfolded rapidly. Many people influenced my career but I did not have any one female role model that inspired my decision to work in science. I sort of stumbled into research. However, my mother was a mighty force, a strong and independent woman. Although getting grants and maintaining funding affects everyone in science, I have always enjoyed the pursuit of science and the people in science. One has to have a love of discovery and adventure and be willing to take failure. Science is a mindset and I think one either has it or not. Science is not about making money; rather, it is the people and the hope and joy of discovery. It is the ideas and the puzzles of nature that provide the rewards and inspiration in science, with the ultimate hope of improving health for everyone.

\section{Some important articles}

Adams J, Liu Z, Ren YA, Wun W-S, Zhou W, Kenigsberg S, Librach C, Valdes C, Gibbons W \& Richards J 2016 Enhanced inflammatory transcriptome in granulosa cells of women with polycystic ovarian syndrome. Journal of Clinical Endocrinology and Metabolism 101 3459-3468. PMID: 27228368.

Espey LL, Yoshioka S, Russell DL, Robker RL, Fujii S \& Richards JS 2000 Ovarian expression of a disintegrin metalloproteinase with thrombospondin motifs during ovulation in the gonadotropin-primed immature rat. Biology of Reproduction 62 1090-1095.

Fan HY, Liu Z, Paquet M, Wang J, Lydon JP, Demayo FJ \& Richards JS 2009a Cell type specific targeted mutation of Kras and Pten document proliferation arrest in granulosa cells versus oncogenic insult in ovarian surface epithelial cells. Cancer Research 69 6463-6472. PMID: 19679546; PMCID: PMC2741085.

Fan HY, Liu Z, Shimada M, Sterneck E, Johnson PF, Hedrick SM \& Richards JS 2009b MAPK3/1 (ERK1/2) in ovarian granulosa cells are essential for female fertility. Science 324 938-941. PMID: 19443782; PMC2847890.

Hernandez-Gonzalez I, Gonzalez-Robayna I, Shimada M, Wayne CM, Ochsner SA, White L \& Richards JS 2006 Gene expression profiles of cumulus cell oocyte complexes during ovulation reveal cumulus cells express neuronal and immune-related genes: does this expand their role in the ovulation process? Molecular Endocrinology 20 1300-1321. PMID: 16455817.

Jahnsen T, Hedin L, Kidd VJ, Beattie WG, Lohmann SM, Walter U, Durica J, Schulz TZ, Schiltz E, Browner M et al. 1986. Molecular cloning, cDNA structure and regulation of the regulatory subunit of type II CAMP-dependent protein kinase from rat ovarian granulosa cells. Journal of Biological Chemistry 261 12352-12361. PMID: 2427518.

Liu Z, Ren YA, Pangas SA, Adams J, Zhou W, Castrillon DH, Wilhelm D \& Richards JS 2015 FOXO1/3 and PTEN depletion in granulosa cells promotes ovarian granulosa cell tumor development. Molecular Endocrinology 29 1006-1024. PMID: 26061565.

Mullany LK, Liu Z, Wong KK, Deneke V, Ren YA, Herron A \& Richards JS 2014 Tumor repressor protein 53 and steroid hormones provide a new paradigm for ovarian cancer metastases. Molecular Endocrinology 28 127-137. PMID: 24264574; PMCID: PMC3874458.

Richards JS 1975 Estradiol receptor content in rat granulosa cells during follicular development: modification by estradiol and gonadotropins. Endocrinology 97 1174-1184. PMID: 171146.

Richards JS, Ireland JJ, Rao MC, Bernath GA, Midgley AR Jr \& Reichert LE Jr 1976 Ovarian follicular development in the rat: hormone receptor regulation by estradiol, follicle stimulating hormone and luteinizing hormone. Endocrinology 99 1562-1570. PMID: 187412.

Shimada M, Gonzalez-Robayna I, Hernandez-Gonzalez I \& Richards JS 2006 Paracrine and autocrine regulation of EGF-like factors in cumulus oocyte complexes and granulosa cells: key role for prostaglandin synthase 2 (Ptgs2) and progesterone receptor (Pgr). Molecular Endocrinology $20348-364$. PMID: 16543407

Sirois J \& Richards JS 1992 Purification and characterization of a novel, distinct isoform of prostaglandin endoperoxide synthase induced by human chorionic gonadotropin in granulosa cells of rat preovulatory follicles. Journal of Biological Chemistry 267 6382-6388. PMID: 1556140.

Sirois J, Simmons DL \& Richards JS 1992 Hormonal regulation of messenger ribonucleic acid encoding a novel isoform of prostaglandin endoperoxide $\mathrm{H}$ synthase in rat preovulatory follicles. Journal of Biological Chemistry 267 11586-11592. PMID: 1597485.

Wong WYW \& Richards JS 1991 Evidence for two antigenically distinct molecular weight variants of prostaglandin $\mathrm{H}$ synthase in the rat ovary. Molecular Endocrinology 5 1269-1279.

an engaging teacher who taught our French class in my senior year of high school and who had just graduated from Oberlin! The summer after my freshman year, I went on a French summer program in France and that was my first time abroad. The adventure was a scary but eyeopening and wonderful experience for a naïve $\mathrm{NH}$ girl! But my goal to become a French major changed in my sophomore year when I had difficulty using headphones to distinguish recorded French conversation (little did I know that I had a hearing problem). I also grew tired of analyzing French literature. Luckily, I was taking all the premed biology courses, not because I was intending to be a premed and go to medical school but because I was keenly interested in biology and eventually, like my mother, biology became my major. I had some traumatic times at Oberlin adjusting to a confining environment away from the mountains, seashore and farm. There was no way to escape by air by sea or by land. Luckily, 


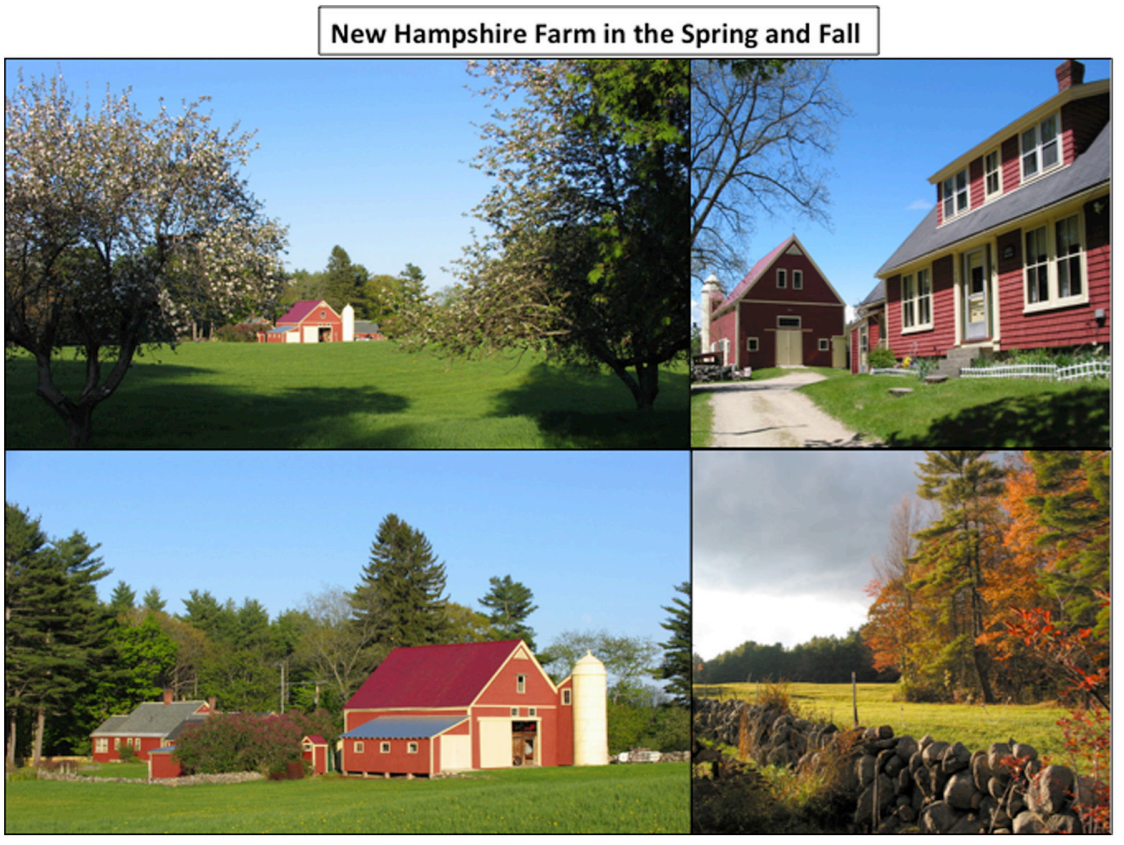

Figure 1 New Hampshire, growing up. New Hampshire is a beautiful state, especially in the spring with lilacs and apple blossoms and in the fall when the landscape is resplendent in flaming colors. Our family farm dating to 1820 provided me with a rich love of nature, hard work in the hay fields and independence. The farm also provided me with a sense of purpose that by a circuitous route eventually led me to science.

there was an ice skating rink, where I could escape but only in the winter!! I did discover tennis but played only sporadically. In the end, I graduated from Oberlin and learned that despite all these years of study and acquisition of 'knowledge', I was absolutely useless and unemployable in the big world. My dear parents had deceived me!!

So, after spending a wonderful summer working in beautiful and exotic Yellowstone Park, I trudged off to graduate school to become a high school biology teacher through the MAT (Master's in Arts and Teaching) program at Brown University. I learned the first day of practicing teaching that this was not my calling because I had absolutely no disciplinary powers whatsoever! Luckily, the program required a research experience and that evolved into my applying for the $\mathrm{PhD}$ program in Physiological Chemistry or Biochemistry at Brown. This was my first exposure to research .... and research in the ovary, with a focus on steroidogenesis, NAD kinase and electron microscopy. Isolating steroid hormones was a big thing in the late 1960s and it was an exciting time! The steroidogenic pathway was being mapped out and the biological functions of these hormones was being discovered. But steroid hormone receptors had not quite yet come on the scene.

\section{Postdoctoral days and the call of research}

After receiving my $\mathrm{PhD}$ degree from Brown University, I spent a year teaching in the Biology Department at the University of North Dakota. This was my second exposure to the American West and the wide-open spaces. It was captivating. I spent two summers teaching on a Native American reservation in Killdeer, ND, hoping to inspire some of Native Americans to teach in their own school systems. But the University Faculty urged me not to stay in ND but to go on for a postdoctoral fellowship. The question was where ... I did not really know anyone and the schools in the West did not have money. So I went through the journal 'Endocrinology', figuring that anyone who was publishing had money and consequently, I joined the Reproductive Endocrinology Program (fondly known as REP) at the University of Michigan (1972). REP had Rockefeller and Ford Foundation grants. This was a time when there was a keen interest to measure peptide and steroid hormones and develop contraceptives! This is where my career in reproductive endocrinology started. Radioactivity had entered the biological world. Radio-immunoassays were being developed and for the very first time allowed endocrinologists to accurately quantitate hormones in serum! Rosalyn Yalow was a co-winner of the 1977 Nobel Prize for the first insulin radioimmunoassay. Prior to this development, hormones could only be measured by laborious bioassays! Now using radioactively labeled reagents and computer technology, many samples could be analyzed rapidly! (The computer at the University of Michigan at that time encompassed an entire building!! Now a laptop can do the same thing.) What a revolution! Radio-immunoassays soon led to radio-receptor assays and the realization that not only hormones in serum but also hormone receptors in tissues were hormonally regulated in a cell-specific manner and changed during follicular development. REP was one of the MECCAs for these new assays.

In the early 1970s, the concept of receptors was just beginning to emerge based on new technologies for radiolabeling protein and steroid hormones. The 
'retention' of these radiolabeled hormones in target tissues led to the concept of specific binding factors or receptors. My research in REP provided some of the first evidence for nuclear estradiol receptors in granulosa cells using nuclear radio-receptor assays (Richards 1975). Subsequently, I with others showed that estradioland $\mathrm{FSH}$-induced receptors for luteinizing hormone (LHCGR) in granulosa cells of rat preovulatory follicles. The acquisition of $\mathrm{LH}$ receptors in granulosa cells of preovulatory follicles determined which follicles ovulate in response to the LH surge. The induction of the LHCGR in preovulatory follicles is now the hallmark of healthy preovulatory follicles in all mammals (Richards 1978, 1979, 1980) (Fig. 2). We also showed that responses of granulosa cells to FSH increased as follicles developed and in response to estradiol. This was not associated with marked changes in $\mathrm{FSH}$ receptor levels, but to other downstream events that actually still remain to be clearly defined but involve enhanced production of cAMP by adenylyl cyclase (Jonassen et al. 1982). We also showed that in corpora lutea of rats, the induction of the LH receptor was dependent on prolactin, not FSH and estradiol! It was a truly awesome and exciting time in ovarian biology including the very first Ovarian Workshop and contacts with ovarian experts of the time (Cornelia Channing, Roger Short, Joanne Fortune, David Armstrong, Jennifer Dorrington, Roy Greep, Griff Ross, Jock Findlay, Mary Hunzicker-Dunn, Gilbert Greenwald; to name just a few). Even though the REP labs were housed in a dark, gloomy, subterranean basement of the medical center, this did not suppress the magnificent glow of research. The world of cell signaling had burst on the scene.

Faculty: A Rees Midgely, Gordon Niswender, P Landis Keyes, Anita Payne, Jerome Menon (Jan Uilenbroek; visiting from the Netherlands).

Postdoctoral Fellows: James Ireland, Riaz Faroohki, John Holt, Ron Carson, Katryna Bogovich (Geula Gibori, postdoc with Landis Keyes).

Graduate students: Meena Rao, Julie Jonassen (Graduate Students with A Rees Midgely: Anthony J Zeleznik, Anne Hirshfield, P Bagavandoss, Michel Sanders).

\section{Establishing a research career in Texas}

Unfortunately and regrettably, things in REP changed and dissolved when a new Chair of Pathology came on board at the University of Michigan. He wanted the space that housed REP! The lesson learned is that institutions don't care about you. Do what you do because you are dedicated to a cause. It was time to move on. I wrote many letters and was surprised, and honored, to hear from Dr Bert O'Malley. I never dreamed I would live in Texas, but I do remember leaving Ann Arbor in a blizzard and arriving on a different flight for Houston where Lutz Birnbaumer was hosting my interview. Although I was

\section{Radio-receptor assays and the induction of the $\mathrm{LH}$ receptor}

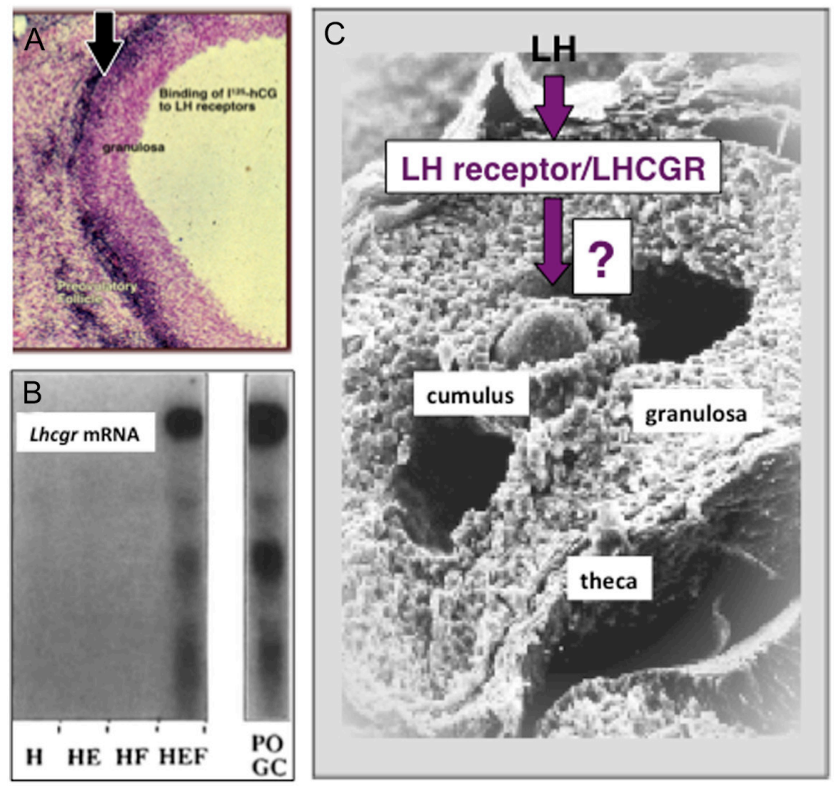

Figure 2 Early-day radio-receptor assays: The 1970s heralded in the use of radioactivity in radio-immuno assays and radio-receptor assays allowing endocrinologists to quantitate hormones and hormone receptors such as the $\mathrm{LH}$ receptor for the very first time. The induction of the LH receptor in granulosa cells of preovulatory follicles was documented not only by radio receptor assays following an i.v. injection of radio-iodinated hCG (panel A; black liver grain) but also following the cloning of the LH receptor gene and Northern Blot analyses of RNA prepared from hypophysectomized $(\mathrm{H})$ rats treated with estradiol (HE), FSH (HF) or estradiol and FSH (HEF) (panel B). A major question plaguing endocrinologists for years was how does $\mathrm{LH}$ acting on mural granulosa cells impact the function of cumulus cells surrounding the oocyte (panel C). (Adapted from Segaloff et al. 1990, Richards et al. 2015).

not on the scheduled flight, we eventually connected ... this was before cell phones! Lutz is also memorable at this time in my career because he was the only person who ever recognized that I was hard of hearing. He came to my defense one time to say, 'She is not stupid, she just can't hear'. I was shocked, and needless to say, quickly got hearing-aids. My ultimate move to the Cell Biology Department at Baylor College of Medicine allowed me to enter yet another new world, that of modern molecular biology and the cloning of genes. It was clear as soon as I arrived that if I didn't have a cloned gene in my pocket I wasn't going anywhere in biology or endocrinology. Surrounded by eminent faculty who supported my early career, my path in molecular endocrinology of the ovary had begun. I am forever indebted. I was also fortunate to have talented postdoctoral fellows from Norway and Sweden who generated the first lamda phage ovarian cDNA library and cloned the type II beta regulatory subunit of cAMPdependent protein kinase (PKA RII beta) using a highly specific antibody from colleagues in Germany, Suzanne Lohmann and Ulrich Walter (Jahnsen et al. 1986). This 
led to further studies to sequence and describe the RII $\beta$ promoter to determine the hormonal regulation RII $\beta$ expression and to analyze the phosphorylation of the protein during follicular development (Ratoosh and Richards 1985, Ratoosh et al. 1987, Kurten et al. 1992).

Following the cloning of RII $\beta$, we then cloned and analyzed promoter activation and the hormonal regulation of genes encoding cholesterol side chain cleavage (CYP11A1) and aromatase (CYP19A1) (Goldring et al. 1987, Hickey et al. 1988, 1990, Oonk et al. 1989, 1990). We collaborated with Deborah Segaloff to analyze the induction of $\mathrm{LH}$ receptor expression in mouse granulosa cells (Segaloff et al. 1990). We also analyzed the hormonal regulation of $\alpha 2$-macroglobuin (Dajee et al. 1996, 1998) and WNT signaling pathway members (Gaddy-Kurten et al. 1989, Hsieh et al. 2002, $2003,2005)$, the latter of which led to analyzing the role of beta-catenin (CTNNB1) in ovarian cancer (Boerboom et al. 2005, 2006). We were excited about the hormonal regulation of gene expression patterns during follicular development (Richards 1994).

Many studies have shown that the FSH and $\mathrm{LH}$ receptors are G-protein-coupled receptors that activate adenylyl cyclase leading to the production of cAMP, activation of cyclic AMP-dependent protein kinase (PKA) and phosphorylation of the transcription factor CREB in ovarian cells. However, CREB is not the only transcription factor regulated by activation of PKA; induction of serum and glucocorticoid-induced kinase (SGK) in granulosa cells depends on GC-rich binding factors such as Sp1 (Alliston et al. 1997, 2000). Moreover, canonical cAMP/ PKA signaling is not they only pathway activated by $\mathrm{FSH}$ in granulosa cells. We showed for the first time that FSH rapidly stimulates the phosphorylation of AKT/ PKB in granulosa cells and that this phosphorylation is not mediated directly by PKA (Gonzalez-Robayna et al. 1999, 2000, Richards 2001). These studies coupled with our analyses of the functions of the AKT target factors, FOXO1 and FOXO3, in granulosa cells have revealed that these transcription factors play key roles in ovarian follicular development by acting with either the activin or BMP signaling pathways to regulate granulosa cell fate decisions, proliferation or apoptosis, respectively (Liu et al. 2009, 2013, 2015b).

Enter the world of transgenic mice! More recently, we have shown that targeted disruption of Foxo1, Foxo3 and Pten in granulosa cells leads to the formation of granulosa cell tumors that exhibit many characteristics of adult granulosa cell tumors (AGCTs) in women; they express FOXL2, WNT4 and GATA4 and show high levels of phosphoSMAD2/3 (Liu et al. 2013, 2015b) (Fig. 3).

\section{The ovulation years}

Prior to 1991, the scientific community thought that a single gene encoded the rate-limiting enzyme in prostaglandin biosynthesis, namely, cyclooxygenase.
Prostaglandin biosynthesis was of keen interest: (1) because ovulation had been coined an inflammatory response' by Dr Espey (Espey 1980), (2) because it was associated with increased prostaglandin biosynthesis and (3) because inhibiting prostaglandin biosynthesis with indomethacin blocked ovulation. Although a cyclooxygenase gene had been cloned, its expression pattern did not match the increase in prostaglandin levels in ovulating follicles. My laboratory had been generating antibodies to purified sheep seminal vesicle cyclooxygenase. Based on differential antibody recognition and molecular weight on Western blots, we unveiled the presence of two immunologically distinct forms of cyclooxygenase, one of which was markedly induced by LH in granulosa cells of ovulating follicles, the other was constitutively expressed in theca cells (Wong \& Richards 1991, Sirois \& Richards 1992, Sirois et al. 1992, 1993, Wong \& Richards 1992, Sirois et al. 1993). Our subsequent purification of the induced protein coincided with the discovery by others of a cyclooxygenase-like gene in chicken embryo fibroblasts that was induced by the Rous sarcoma virus. The deduced amino acid sequence of the chicken gene matched the $\mathrm{N}$-terminal amino sequence of the mouse protein and paved the way for our documenting that ovulating follicles expressed a second, distinct form of cyclooxygenase, now known as COX-2 or PTGS2 (prostaglandin synthase-2) (Sirois \& Richards 1992, 1993, Sirois et al. 1992, 1993). The induction of this inducible PTGS2 protein is essential for cumulus celloocyte complex (COC) expansion. Disruption of the Ptgs2 gene by others confirmed that it was essential for ovulation and that COC expansion is obligatory for ovulation (Fig. 4).

These discoveries in the early 1990s paved the way for our later studies on the molecular events that control LH-mediated induction of ovulation and the essential roles of specific genes, in addition to Ptgs 2, that control COC expansion. Genes induced by the LH surge and determined to be critical for COC expansion include the EGF-like factors (Areg, Ereg, Btc), hyaluronic acid synthase 2 (Has2) and tumor necrosis factor alphainduced protein 6 (Tnfaip6) that with pentraxin 3 (Ptx3) and the serum protein inter alpha inhibitor $(\alpha)$ form a scaffold of proteins that stabilize the expanded COC matrix; this stabilization is critical for the release of COCs during ovulation (Richards et al. 2002, 2008, 2015, Richards 2005, 2007, Hernandez-Gonzalez et al. 2006, Richards \& Pangas 2010, Richards \& Ascoli 2018). We identified these genes by microarray analyses of COCs isolated from periovulatory follicles at specific times following administration of hCG/LH to eCGprimed immature mice and by culturing isolated COCs in vitro in the presence of AREG or EREG (Shimada et al. 2005, 2006, Hernandez-Gonzalez et al. 2006). Other genes that are induced by the LH surge and critical for follicle rupture and ovulation include the 


\section{Granulosa Cell Tumor Formation/Altered Cell Fate}

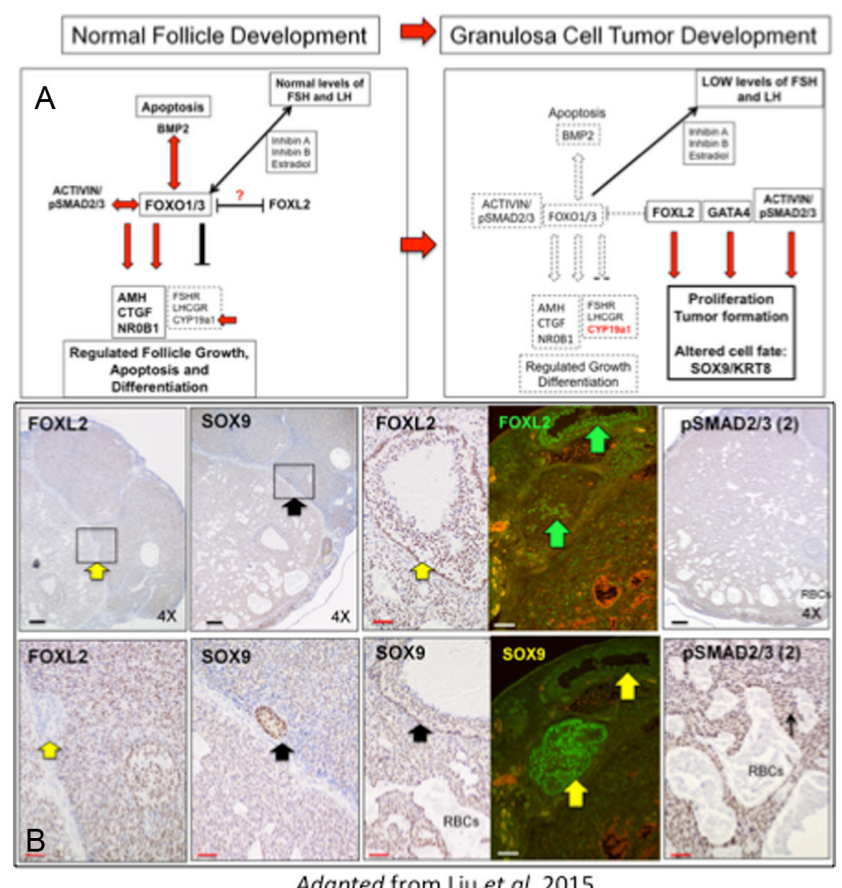

Adapted from Liu et al, 2015

Figure 3 Granulosa cell tumor formation/altered cell fate: The transcription factor FOXO1 is highly expressed in granulosa cells where it acts to control follicle growth and apoptosis by interacting with the activin or BMP2 pathways, selectively and respectively, to regulate specific genes. Depletion of FOXO1/3 in granulosa cells leads to granulosa cell tumor growth that is even more pronounced if the Pten gene is also depleted. Some of the mutant granulosa cells acquire distinct cell fates as indicated by the expression of SOX9, a marker of Sertoli cells and epithelial cells. (Adapted from Liu et al. 2015b).

progesterone receptor (PGR) (Park \& Mayo 1991), a PGR target gene Adamts 1 (Espey et al. 2000, Russell et al. 2003a) and versican (Russell et al. 2003b). Although the PGR-null mice fail to ovulate, the granulosa cells luteinize, indicating that the targets of PGR controlling rupture, such as endothelin 2 (Ko et al. 2006, 2012) are highly specific and restricted: new targets are still being analyzed by others. Disruption of cyclin D2 also leads to ovulation failure, likely because there are so few granulosa cells and cumulus cells present in the developing follicles (Robker \& Richards 1998). The Tollreceptor pathway is also expressed in cumulus cells and may impact ovulation as well as fertilization (Liu et al. 2008, Richards et al. 2008) (Fig. 4).

Because LHCGR receptors are localized to mural granulosa cells but not cumulus cells, the molecular mechanisms by which LH-mediated COC expansion eluded endocrinologists for years until the discovery that $\mathrm{LH}$ induced the expression of the EGF-like factors that then (1) bound EGF receptors in granulosa cells and cumulus cells, (2) activated the RAS-MAP-kinase and ERK1/2 pathways (3) that then activated specific transcription factors including C/EBP alpha and C/EBP beta (Fan et al. 2008, 2009b, 2011). By targeted depletion of Erk2 in Erk1-null mice, we documented unequivocally that ERK1/2 control the master switch that suppresses the FSH-driven molecular program in granulosa cells of growing follicles and induces COC expansion (all genes controlling matrix formation and stabilization), meiotic resumption in oocytes (cGMP), ovulation (genes involved in rupture; PGR) and luteinization (cytokines and vascularization factors) in preovulatory follicles. By targeted depletion of Cebpa and Cebpb, we have documented further that these transcription factors are obligatory for ovulation and the regulation of specific genes controlling vascularization of the newly formed corpus luteum (Fan et al. 2011).

\section{Entry into the world of ovarian cancer}

The critical role of RAS activation of ERK $1 / 2$ in granulosa cells of ovulating follicles led us to ask what effects premature expression of RAS would exert in small growing follicles. To address this, we targeted the expression of a constitutively active form of RAS, namely KRASG12D, to granulosa cells using mice expressing Amhr-2-Cre. We were surprised that the expression of active KRAS ${ }^{\mathrm{G} 12 \mathrm{D}}$ blocked follicle growth, reduced ovarian steroid production and led to increased expression of the tumor suppressor gene, PTEN; granulosa cell proliferation and apoptosis ceased and small abnormal follicles accumulated in the ovaries (Fan et al. 2008). When we disrupted Pten in the Kras mutant mice to reverse the effects of KRAS, follicle development was still blocked (Fan et al. 2009a). In striking contrast, in the same ovaries, the ovarian surface epithelial cells (that are also targeted by Amhr2-Cre) were transformed and provided us with the first model of ovarian surface epithelial cancer that occurred early and was 100\% penetrant (Fan et al. 2009a). These mice are also unique because endogenous ovarian steroid hormone production is drastically reduced thereby allowing us to determine the effects of exogenous estradiol and/ or progesterone on primary ovarian tumor growth and metastasis in situ. By depleting the tumor repressor protein 53 (Trp53; p53) gene in the Kras/Pten mutant mice, we discovered that wild-type p53 is essential for tumor growth, whereas cells lacking p53 develop only small tumor lesions (Mullany et al. 2014). However, the p53-null cells, unlike cell expressing WT p53, are exquisitely sensitive to steroid hormones and become highly metastatic when exposed to exogenous estradiol (Mullany et al. 2014). Expressing the p53 R172H mutant in this Kras/Pten mouse strain leads to rampant metastasis if the mutant alleles are homozygous and also to serous and mucinous-type tumors in cells expressing a wild-type and mutant allele. The heterozygous tumors are also highly sensitive to estradiol (Ren et al. 2016) (Fig. 5). 


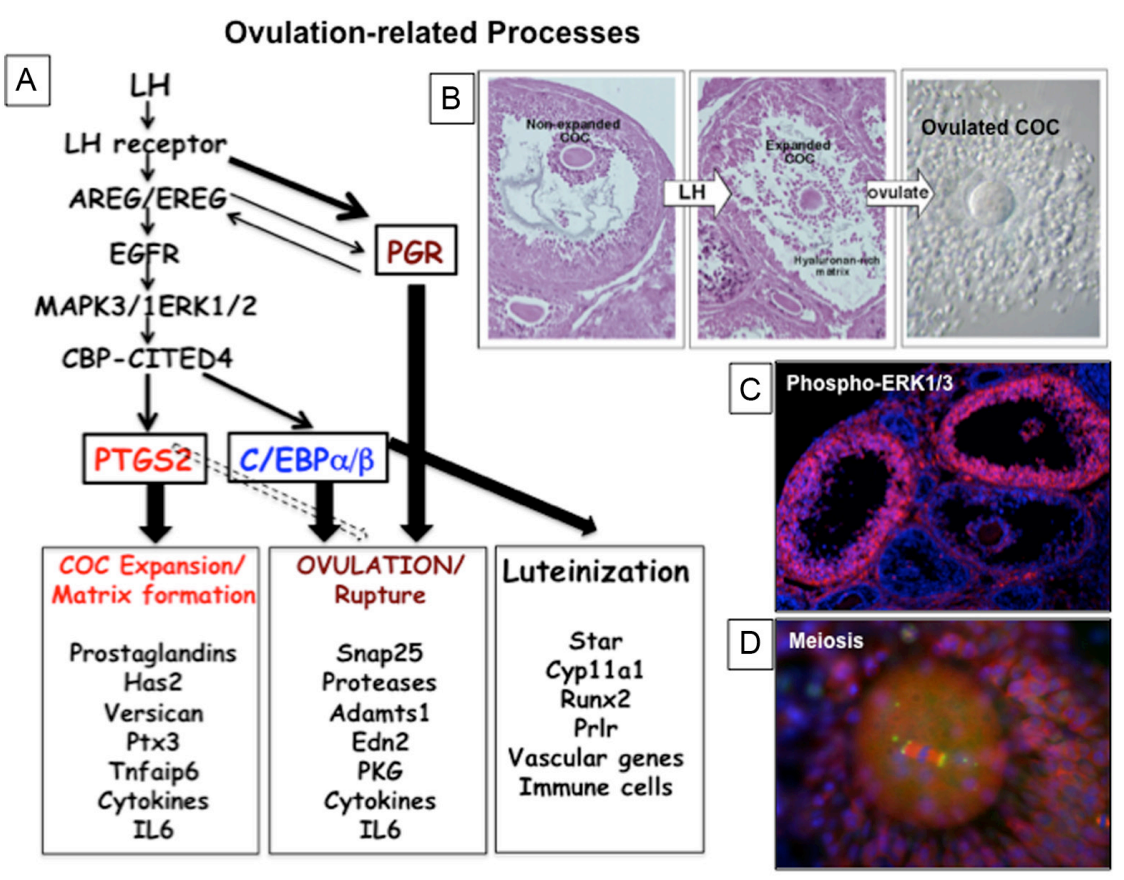

Figure 4 Ovulation-related processes. The LH surge initiates a remarkable cascade of signaling and molecular events (panel A) that control cumulus cell-oocyte complex (COC) expansion, ovulation and luteinization (panel $B)$. Key to these events is the induction of the EGF-like factors, AREG, EREG and BTC, in granulosa cells that bind and activate EGF receptors in granulosa and cumulus cells and lead to activation of ERK1/2 (panel C). Also critical is the induction of the progesterone receptor (PGR). Furthermore, the $\mathrm{LH}$ surge leads to the initiation of meiosis in oocytes by regulating cGMP levels in cumulus cells and the oocyte (panel D). (Adapted from Richards \& Pangas 2010, Richards et al. 2015).
There are many mutations in p53 in ovarian cancer cells. Some p53 mutant proteins are inactive; other mutant proteins acquire gain-of-function (GOF) oncogenic activities that promote ovarian cancer growth. We have become interested in these GOF mutant proteins and their impact on tumor growth and metastasis, responses to steroid hormones and their abilities to evade immune attack. Thus, our current studies are focused on determining how specific GOF $\mathrm{R} 175 \mathrm{H}, \mathrm{R} 273 \mathrm{H}$ and $\mathrm{R} 248 \mathrm{Q}$ mutant p53 alleles impact the growth of ovarian cancer cells in the same Kras/Pten genetic background. We already know that the $\mathrm{R} 175 \mathrm{H}$ p53 mutant protein behaves differently than the R273H and $\mathrm{R} 248 \mathrm{Q}$ mutant $\mathrm{p} 53$ proteins in response to cytotoxic drugs and in tumor morphology (Padmanabhan et al. 2018). Thus, we anticipate finding distinct mechanisms by which each of these regulates responses to steroids and the immune cell microenvironment.

The power and force by which these cancer cells grow and metastasize is impossible to ignore and has had a huge impact on my view of biological regulatory mechanisms. One wants to conquer these cells and learn how to kill them, but how? It is amazing that man has not yet figured this out ... maybe we are coming closer with our understanding of the immune system. Moreover, the power by which different oncogenes interact is sometimes surprising. For example, in transgenic mice expressing either KRAS ${ }^{\mathrm{G} 12 \mathrm{D}}$ or lacking PTEN profoundly affects the ability of a constitutively active form of beta-catenin (CTNNB1) to promote granulosa cells tumor formation (Richards et al. 2012). What is most remarkable is that the gene profiles in the granulosa cell tumors expressing mutant CTNNB1 and KRAS ${ }^{\mathrm{G} 12 \mathrm{D}}$ are essentially identical to those tumors expressing CTNNB1 in the absence of PTEN. One conclusion is that mutant active CTNNB1 is driving the tumor phenotype and either KRAS ${ }^{\mathrm{G} 12 \mathrm{D}}$ or loss of PTEN promotes the CTNNB1-mediated program.

\section{New projects: theca cell functions and dysfunction in women's health}

Premature ovarian failure (POF), polycystic ovarian syndrome (PCOS) and ovarian hyperthecosis $(\mathrm{OH})$ are disorders in women where theca cell functions appear to be abnormal. In some cases of POF, theca cell recruitment to primary/secondary follicles may be impaired because oocyte production of GDF9 is reduced. This leads to impaired induction of hedge-hog signaling ligands ( $\mathrm{IHH}$ and $\mathrm{DHH}$ ) in granulosa cells that, in turn, prevents the recruitment of stromal theca cells. Hence, theca androgen-producing cells are lacking (Liu et al. 2015a). Conversely, theca cells in PCOS and $\mathrm{OH}$ patients overproduce androgens leading to complex local and systemic effects, including insulin resistance, obesity and a proinflammatory state (Dumesic \& Richards 2013, Richards et al. 2018). We have recently analyzed and identified inflammatory events associated with periovulatory follicles of PCOS patients undergoing IVF and showed that granulosa cells obtained from follicles of obese PCOS patients produce more cytokines than those of lean PCOS patients (Adams et al. 2016). These studies have led to our current interest in how elevated androgens and cytokines interact to control ovarian follicle growth, PCOS and the follicular microenvironment. 


\section{A Mouse Model of Ovarian Cancer}
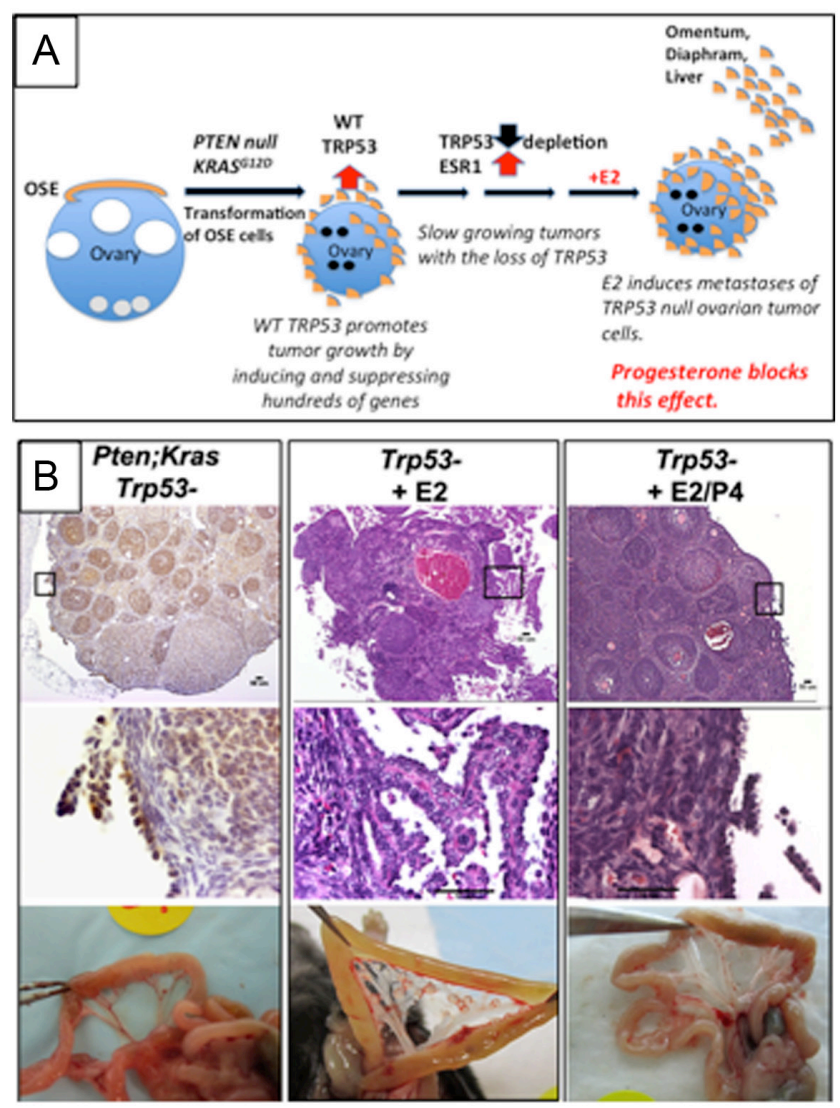

Adapted from Mullany et al, 2014

Figure $5 \mathrm{~A}$ mouse model of ovarian cancer. Mutant mice were generated to express granulosa cell-specific expression of a constitutively active form of KRAS, KRAS ${ }^{\mathrm{G} 12 \mathrm{D}}$, by mating mice harboring the LSL-Kras ${ }^{\mathrm{G} 12 \mathrm{D}}$ gene to mice with Amhr2-cre recombinase (panel A). Expression of the mutant KRAS in granulosa cells blocked follicular development (pane A: transition from white to black circles) leading to ovaries with severe loss of steroidogenesis. These abnormal follicles expressed elevated levels of the tumor suppressor PTEN. In an attempt to revert follicular development back to a normal state, Pten was deleted in these mice by mating the Kras;Amhr2-cre mutant mice to Pten ${ }^{\text {fl/fl }}$ mice. Although disrupting Pten in the granulosa cells had no effect on follicle growth, it caused ovarian surface epithelial (OSE) cells to transform. These mutant OSE cells expressed WTp53 that when deleted led to severe suppression of tumor growth indicating that WT p53 supported tumor growth. Remarkably, depletion of p53 impaired tumor growth and only small lesions were observed (panel B). However, estradiol potently stimulated tumor growth of the p53 null tumor cells; progesterone blocked this effect (panels A and B). This mouse model has provided a unique in vivo system in which to analyze the effects of steroids on tumor formation and metastasis. (Adapted from Mullany et al. 2014).

The role of androgens and the androgen receptor (AR, NR3C4) in follicular development has primarily focused on how they impact granulosa cell functions, whereas the potential impact of androgens and the role of AR on theca and stromal/interstitial cells have been largely overlooked (Richards et al. 2018). The oversight is especially evident at the molecular level, despite the fact that mouse and human theca cells express both the AR and the modulator of AR action co-repressor COUPTF-II/ NR2F2. A recent theca cell-specific androgen receptor (AR)-knockout mouse model documents that the loss of AR selectively in theca cells prevents androgens from promoting a PCOS-like phenotype in an androgentreated mutant mouse model (Ma et al. 2017). This key observation clearly implicates not only elevated theca cell androgens but also theca cell AR as potential culprits of changes in theca cell functions, including inflammatory events that contribute to PCOS. Using a DHT-treated mouse model, we have observed profound changes in AR-positive and NR2F2-positive cells in the theca/stroma compartment and the induction of specific genes. We hypothesize that elevated androgens alter AR regulation of theca cell functions leading to specific changes in cellular and molecular events that underlie and/or contribute to ovarian dysfunction in PCOS and $\mathrm{OH}$ (Candelaria et al. 2018, 2019) (Fig. 6).

Faculty: BertW O'Malley, Anthony R Means, Jim Clark, Lutz Birnbaumer, Mariel Birnbaumer, Jeffrey Rosen, William Schrader, Nancy Weigel, Franco DeMayo, Orla Conneely, Stephanie Pangas (Visiting faculty in my lab, chronological order: Lou DePaola, Joseph Orly, Joanne Fortune, Lawrence Espey, Masayuki Shimada).

Postdoctoral Fellows: Tore Jansen, Lars Hedin, Gerald Hickey, Ria Oonk, Susan Fitzpatrick Jeffrey Clemens, Jean Sirois, Diana Carlone, Darryl Russell, Chidananda Sharma, Ignacio Gonzalez-Robayna, Derek Boerboom Chad Wayne, Michael Rudd, Heng-Yu Fan, Zhilin Liu, Lisa Mullany, Yi Ren, Jaye Adams, Nicholes Candelaria, Achuth Padmanabhan.

Graduate Students: Sheri Ratoosh, Jami Lifka, Richard Kurten, Winona Wong, Dana Gaddy, Rebecca Robker, Jaqueline Morris, Tamara Alliston, Maya Dajee, Scott Ochsner, Kari Heidel, Minnie Hsieh, Allison Falender.

\section{What makes science so much fun and rewarding?}

My life in science came as a surprise, a discovery! It was not a childhood dream; it was not planned. Even today, I do not actually think of myself as a 'scientist'. What I enjoy and what has captured me is the process of discovery and the challenges to decipher the secrets of mother nature. Most rewarding have been the unexpected results that have led me down new paths and reminded me that one should always keep an open mind! When experiments do not seem to work but when it is not due to technical issues, then there is likely something significant and important to be found. For my lab it has been: identifying a new cyclooxygenase gene, generating an unexpected mouse model of ovarian cancer, identifying novel pathways regulating ovulation and documenting a novel role for androgens in theca/stromal cells. In these discoveries, I have enjoyed the enthusiasm of young students and colleagues (Fig. 7). 


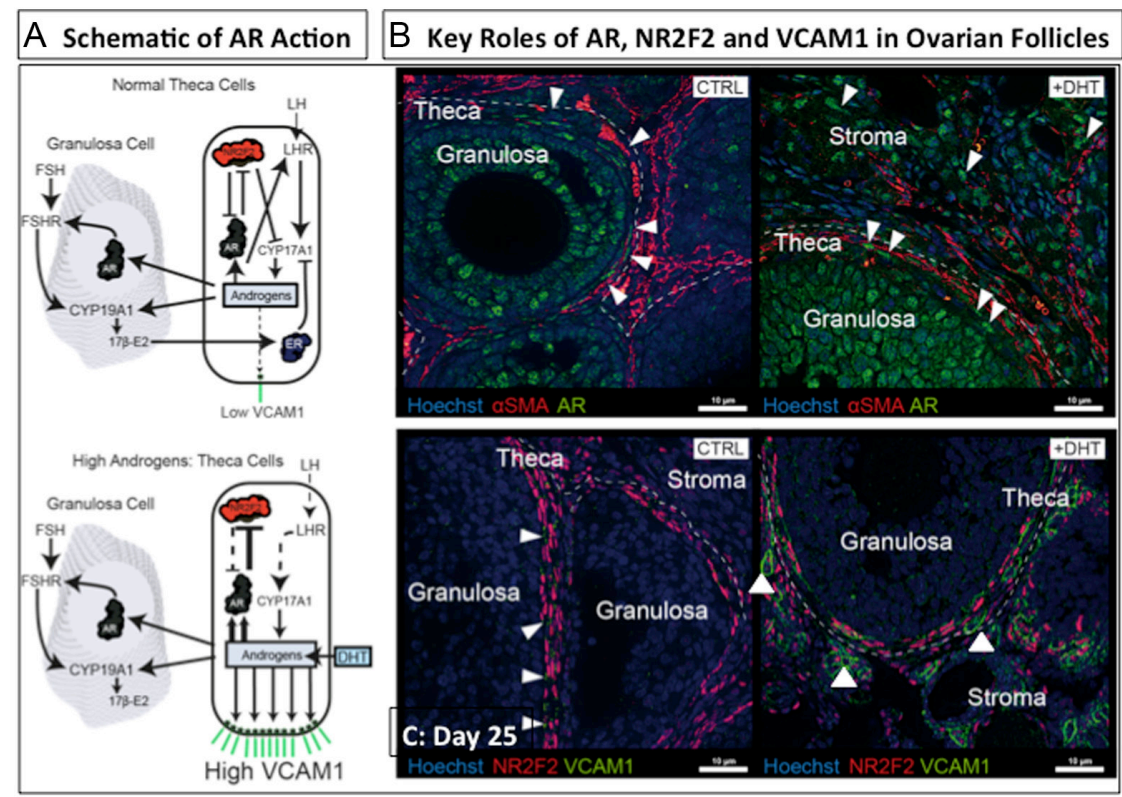

Figure 6 (A) Schematic of a mouse model of androgen excess and PCOS. (B) Key roles of AR, NR2F2 and VCAM1 in theca cells. The androgen receptor (AR) is expressed in theca cells as well as granulosa cells of follicles in control Day 25 and DHT-treated mice (panels $A$ and $B$ ) and impacts theca cell functions along with the AR co-modulatory regulator NR2F2. NR2F2 is exclusively expressed in theca cells and together with AR they comprise and regulatory feedback system (panels A and B). Excess androgen DHT leads to the expansion of theca/stromal cells that express not only AR and NR2F2 but also elevated levels of vascular cell adhesion molecule 1 (VCAM1). VCAM1 appears to be essential for follicular integrity. A similar AR, NR2F2 and VCAM1 regulatory system appears to occur in theca cells of PCOS patients. (White arrowheads indicate theca AR (green, upper panels) and VCAM1 (green, lower panels)). (Adapted from Candelaria et al., SSR Meeting 2018)
I have enjoyed being the Director of the Graduate Program in the Molecular and Cellular Biology Department for over 25 years. Luckily, my life and research career has been blessed with many wonderful students, fellows, colleagues and collaborators. I have never really felt that being a woman hindered my science or my career path because both women and men have supported my efforts. I enjoy the interactions, discussions and trust in sharing ideas with others; the trust in sharing precious reagents. As an example, Dan Simmons at the University of Utah had just published his paper on the cyclooxygenase-like gene in chicken embryo fibroblasts that was induced by the Rous Sarcoma Virus. I did not know him, but I called him (this was before email!) to see if he would collaborate and send a cDNA clone for us to test in granulosa cells of ovulating follicles. By then, he had the mouse cDNA and sent it immediately. This CDNA was a treasure in our efforts to determine whether or not a distinct gene encoded the inducible cyclooxygenase-like protein observed in ovulating follicles (Simmons et al. 1992, Sirois et al. 1992, 1993). We were thrilled to see a positive, highly induced signal on Northern Blots (this was before gPCR!). The inducible RNA was there and only induced by LH! It was like winning the Wimbledon or an Olympic medal. Of special note, I have yet to meet Dan Simmons in person! He certainly gave us a great gift for which we have been forever grateful. There are many other examples: Deborah Segaloff and her long-standing efforts to clone the $\mathrm{LH}$ receptor and then share the probe with my lab (Segaloff et al. 1990), Dagmar Wilhelm for sending her treasured FOXL2 antibody (and I still have not met her!) (Liu et al. 2015b), and many more.

Science is driven by ideas and technology; scientists are rewarded by discovering new pathways, genes and approaches to understand basic biological processes such as ovulation and PCOS and to open doors for improving and controlling cancer. I have been richly rewarded throughout my career. None of this would be possible without the support of the Society for the Study of Reproduction, the Endocrine Society and the National Institutes of Health. These organizations and the wonderful, dedicated people who maintain these scientific and educational opportunities are the ones who sustain our research in endocrinology and reproductive biology.

My career in science has been balanced by my dedication to sports. In Houston, I continued my love of ice-skating and managed to pass all of the USFSA compulsory ice dancing tests to the gold level. In addition, I love to jog, swim and hike. My husband Phil and I have backpacked across and camped in the Grand

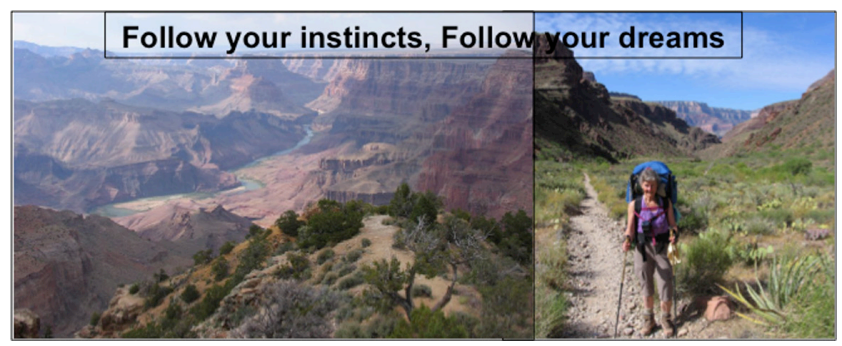

Figure 7 Follow your instincts and dreams. Life is not linear. So follow your instincts and follow your dreams. But listen to others and if asked, participate! There is always something new to learn and discoveries to be made! When something is not working like it should, pay attention. Something new may emerge. What seems like a failure can lead to success. Persevere! And most of all, just when you think you have hiked the Grand Canyon for the last time, you will just keep trekking. 
Canyon for the last 9 years. Because I cannot have horses in my back yard in Houston, I have cats!

\section{Declaration of interest}

The author declares that there is no conflict of interest that could be perceived as prejudicing the impartiality of this review.

\section{Funding}

NIH-HD-076980 and HD-CA181080 (current) and NIH-HD-16229 and NIH-HD-16272 (previous).

\section{References}

Adams J, Liu Z, Ren YA, Wun WS, Zhou W, Kenigsberg S, Librach C, Valdes C, Gibbons W \& Richards J 2016 Enhanced inflammatory transcriptome in the granulosa cells of women with polycystic ovarian syndrome. Journal of Clinical Endocrinology and Metabolism 101 3459-3468. (https://doi.org/10.1210/jc.2015-4275)

Alliston TN, Maiyar AC, Buse P, Firestone GL \& Richards JS 1997 Follicle stimulating hormone-regulated expression of serum/glucocorticoidinducible kinase in rat ovarian granulosa cells: a functional role for the Sp1 family in promoter activity. Molecular Endocrinology 11 1934-1949. (https://doi.org/10.1210/mend.11.13.0033)

Alliston TN, Gonzalez-Robayna IJ, Buse P, Firestone GL \& Richards JS 2000 Expression and localization of serum/glucocorticoid-induced kinase in the rat ovary: relation to follicular growth and differentiation. Endocrinology 141 385-395. (https://doi.org/10.1210/endo.141.1.7257)

Boerboom D, Paquet M, Hsieh M, Liu J, Jamin SP, Behringer RR, Sirois J, Taketo MM \& Richards JS 2005 Misregulated Wnt/beta-catenin signaling leads to ovarian granulosa cell tumor development. Cancer Research 65 9206-9215. (https://doi.org/10.1158/0008-5472.CAN-05-1024)

Boerboom D, White LD, Dalle S, Courty J \& Richards JS 2006 Dominantstable beta-catenin expression causes cell fate alterations and Wnt signaling antagonist expression in a murine granulosa cell tumor model. Cancer Research 66 1964-1973. (https://doi.org/10.1158/0008-5472. CAN-05-3493)

Candelaria NR, Padmanabhan A, Stossi F, Ljungberg MC, Shelly K, Pew BK, Solis M, Rossano AM, Mcallister JM, Wu S et al. 2017 Androgen action in the ovary of a PCOS mouse model. Annual Meeting of the Society for the Study of Reproduction, Poster 409. Abstract.

Candelaria NR, Padmanabhan A, Stossi F, Ljungberg MC, Shelly K, Pew BK, Solis M, Rossano AM, Mcallister IM, Wu S et al. 2018 Androgens impact theca and stroma cell functions: new targets that contribute to ovarian function and dysfunction in androgen excess. Annual Meeting of the Society for the Study of Reproduction, Poster 125. Abstract.

Candelaria NR, Padmanabhan A, Stossi F, Ljungberg MC, Shelly KE, Pew BK, Solis M, Rossano AM, McAllister JM, Wu S, Richards JS 2019 VCAM1 expression is induced in ovarian theca and interstitial cells in a mouse model of androgen excess. Endocrinology (in press)

Dajee M, Fey GH \& Richards JS 1998 Stat 5b and the orphan nuclear receptors regulate expression of the alpha2-macroglobulin (a2M) gene in rat ovarian granulosa cells. Molecular Endocrinology 12 1393-1409. (https://doi.org/10.1210/mend.12.9.0161)

Dajee M, Kazansky AV, Raught B, Hocke GM, Fey GH \& Richards JS 1996 Prolactin induction of the alpha 2-Macroglobulin gene in rat ovarian granulosa cells: stat 5 activation and binding to the interleukin- 6 response element. Molecular Endocrinology 10 171-184. (https://doi. org/10.1210/mend.10.2.8825557)

Dumesic DA \& Richards JS 2013 Ontogeny of the ovary in polycystic ovary syndrome. Fertility and Sterility 100 23-38. (https://doi.org/10.1016/j. fertnstert.2013.02.011)

Espey LL 1980 Ovulation as an inflammatory reaction--a hypothesis. Biology of Reproduction 22 73-106. (https://doi.org/10.1095/biolreprod22.1.73)

Espey LL, Yoshioka S, Russell DL, Robker RL, Fujii S \& Richards JS 2000 Ovarian expression of a disintegrin metalloproteinase with thrombospondin motifs during ovulation in the gonadotropin-primed immature rat. Biology of Reproduction 62 1090-1095. (https://doi. org/10.1095/biolreprod62.4.1090)

Fan HY, Shimada M, Liu Z, Cahill N, Noma N, Wu Y, Gossen J \& Richards JS 2008 Selective expression of Kras ${ }^{\mathrm{G} 12 \mathrm{D}}$ in granulosa cells of the mouse ovary causes defects in follicular development and ovulation. Development 135 2127-2137. (https://doi.org/10.1242/dev.020560)

Fan HY, Liu Z, Paquet M, Wang J, Lydon JP, Demayo FJ \& Richards JS 2009a Cell type specific targeted mutation of Kras and Pten document proliferation arrest in granulosa cells versus oncogenic insult in ovarian surface epithelial cells. Cancer Research 69 6463-6472. (https://doi. org/10.1158/0008-5472.CAN-08-3363)

Fan HY, Liu Z, Shimada M, Sterneck E, Johnson PF, Hedrick SM \& Richards JS 2009b MAPK3/1 (ERK1/2) in ovarian granulosa cells are essential for female fertility. Science 324 938-941. (https://doi. org/10.1126/science.1171396)

Fan HY, Liu Z, Johnson PF \& Richards JS 2011 CCAAT/enhancer-binding proteins (C/EBP)-\{alpha\} and -\{beta\} are essential for ovulation, luteinization and expression of key target genes. Molecular Endocrinology 25 253-268. (https://doi.org/10.1210/me.2010-0318)

Gaddy-Kurten D, Hickey GJ, Fey GH, Gauldie J \& Richards JS 1989 Hormonal regulation and tissue-specific localization of alpha 2 -macroglobulin in rat ovarian follicles and corpora lutea. Endocrinology 125 2985-2995. (https://doi.org/10.1210/endo-125-6-2985)

Goldring NB, Durica JM, Lifka J, Hedin L, Ratoosh SL, Miller WL, Orly J \& Richards JS 1987 Hormonal regulation of cholesterol side chain cleavage P-450 (P-450scc) mRNA in rat ovarian follicles and corpora lutea. Endocrinology 120 1942-1950. (https://doi.org/10.1210/endo120-5-1942)

Gonzalez-Robayna IJ, Alliston TN, Buse P, Firestone GL \& Richards JS 1999 Functional and subcellular changes in the A-kinase signaling pathway: relation to aromatase and SGK expression during the transition of granulosa cells to luteal cells. Molecular Endocrinology $\mathbf{1 3}$ 1318-1337. (https://doi.org/10.1210/mend.13.8.0334)

Gonzalez-Robayna IJ, Falender AE, Ochsner S, Firestone GL \& Richards JS 2000 Follicle-Stimulating hormone (FSH) stimulates phosphorylation and activation of protein kinase B (PKB/Akt) and serum and glucocorticoidInduced kinase (Sgk): evidence for A kinase-independent signaling by FSH in granulosa cells. Molecular Endocrinology 14 1283-1300. (https:// doi.org/10.1210/mend.14.8.0500)

Hernandez-Gonzalez I, Gonzalez-Robayna I, Shimada M, Wayne CM, Ochsner SA, White L \& Richards JS 2006 Gene expression profiles of cumulus cell oocyte complexes during ovulation reveal cumulus cells express neuronal and immune-related genes: does this expand their role in the ovulation process? Molecular Endocrinology 20 1300-1321. (https://doi.org/10.1210/me.2005-0420)

Hickey GJ, Krasnow JS, Beattie WG \& Richards JS 1990 Aromatase cytochrome P450 in rat ovarian granulosa cells before and after luteinization: adenosine $3^{\prime}, 5^{\prime}$-monophosphate-dependent and independent regulation. Cloning and sequencing of rat aromatase cDNA and 5' genomic DNA. Molecular Endocrinology 4 3-12. (https://doi. org/10.1210/mend-4-1-3)

Hickey GJ, Chen SA, Besman MJ, Shively JE, Hall PF, Gaddy-Kurten D \& Richards JS 1988 Hormonal regulation, tissue distribution, and content of aromatase cytochrome P450 messenger ribonucleic acid and enzyme in rat ovarian follicles and corpora lutea: relationship to estradiol biosynthesis. Endocrinology 122 1426-1436. (https://doi.org/10.1210/ endo-122-4-1426)

Hsieh M, Johnson M, Greenberg NM \& Richards JS 2002 Regulated expression of Wnt and Frizzled signals in the rodent ovary. Endocrinology 143 898-908. (https://doi.org/10.1210/endo.143.3.8684)

Hsieh M, Mulders SM, Friis RR, Dharmarajan A \& Richards JS 2003 Expression and localization of secreted frizzled-related protein 4 in the rodent ovary: evidence for selective up-regulation in luteinized granulosa cells. Endocrinology 144 4597-4606. (https://doi.org/10.1210/en.20030048)

Hsieh M, Boerboom D, Shimada M, Lo Y, Parlow AR, Luhmann UF, Berger W \& Richards JS 2005 Mice null for frizzled4 (Fzd4-/-) are infertile and exhibit impaired corpora lutea formation and function. Biology of Reproduction 73 1135-1146.

Jahnsen T, Hedin L, Kidd VJ, Beattie WG, Lohmann SM, Walter U, Durica J, Schulz TZ, Schiltz E \& Browner M 1986 Molecular cloning, 
cDNA structure and regulation of the regulatory subunit of type II CAMPdependent protein kinase from rat ovarian granulosa cells. Journal of Biological Chemistry 261 12352-12361.

Jonassen JA, Bose K \& Richards JS 1982 Enhancement and desensitization of hormone-responsive adenylate cyclase in granulosa cells of preantral and antral ovarian follicles: effects of estradiol and follicle-stimulating hormone. Endocrinology 111 74-79. (https://doi.org/10.1210/endo-1111-74)

Ko C, Gieske MC, Al-Alem L, Hahn Y, Su W, Gong MC, Iglarz M \& Koo Y 2006 Endothelin-2 in ovarian follicle rupture. Endocrinology 147 1770-1779. (https://doi.org/10.1210/en.2005-1228)

Ko C, Meidan R \& Bridges PJ 2012 Why two endothelins and two receptors for ovulation and luteal regulation? Life Sciences 91 501-506. (https:// doi.org/10.1016/j.Ifs.2012.05.010)

Kurten RC, Levy LO, Shey J, Durica JM \& Richards JS 1992 Identification and characterization of the GC-rich and cyclic adenosine 3',5'-monophosphate (cAMP)-inducible promoter of the type II beta cAMP-dependent protein kinase regulatory subunit gene. Molecular Endocrinology 6 536-550. (https://doi.org/10.1210/mend.6.4.1316546)

Liu Z, Shimada M \& Richards JS 2008 The involvement of the Toll-like receptor family in ovulation. Journal of Assisted Reproduction and Genetics 25 223-228. (https://doi.org/10.1007/s10815-008-9219-0)

Liu Z, Rudd MD, Gonzalez-Robayna I, Fan HY, Zeleznik AJ \& Richards JS 2009 FSH and FOXO1 regulate genes in the sterol/steroid and lipid biosynthesis pathways in granulosa cells. Molecular Endocrinology 23 649-661. (https://doi.org/10.1210/me.2008-0412)

Liu Z, Castrillon DH, Zhou W \& Richards JS 2013 FOXO1/3 depletion in granulosa cells alters follicle growth, death and regulation of pituitary FSH. Molecular Endocrinology 27 238-252. (https://doi.org/10.1210/ me.2012-1296)

Liu C, Peng J, Matzuk MM \& Yao HH-C 2015a Lineage specification of ovarian theca cells requires multicellular interactions via oocyte and granulosa cells. Nature Communications 6 6934-6934. (https://doi. org/10.1038/ncomms7934)

Liu Z, Ren YA, Pangas SA, Adams J, Zhou W, Castrillon DH, Wilhelm D \& Richards JS 2015b FOXO1/3 and PTEN depletion in granulosa cells promotes ovarian granulosa cell tumor development. Molecular Endocrinology 29 1006-1024. (https://doi.org/10.1210/me.2015-1103)

Ma Y, Andrisse S, Chen Y, Childress S, Xue P, Wang Z, Jones D, Ko C, Divall S \& Wu S 2017 Androgen receptor in the ovary theca cells plays a critical role in androgen-induced reproductive dysfunction. Endocrinology 158 98-108. (https://doi.org/10.1210/en.2016-1608)

Mullany LK, Liu Z, Wong KK, Deneke V, Ren YA, Herron A \& Richards JS 2014 Tumor repressor protein 53 and steroid hormones provide a new paradigm for ovarian cancer metastases. Molecular Endocrinology 28 127-137. (https://doi.org/10.1210/me.2013-1308)

Oonk RB, Krasnow JS, Beattie WG \& Richards JS 1989 Cyclic AMPdependent and -independent regulation of cholesterol side chain cleavage cytochrome P-450 (P-450scc) in rat ovarian granulosa cells and corpora lutea. cDNA and deduced amino acid sequence of rat P-450scc. Journal of Biological Chemistry $26421934-21942$.

Oonk RB, Parker KL, Gibson JL \& Richards JS 1990 Rat cholesterol side-chain cleavage cytochrome P-450 (P-450scc) gene. Structure and regulation by CAMP in vitro. Journal of Biological Chemistry 265 22392-22401.

Padmanabhan A, Candelaria N, Wong KK, Nikolai BC, Lonard DM, O'Malley BW \& Richards JS 2018 USP15-dependent lysosomal pathway controls p53-R175H turnover in ovarian cancer cells. Nature Communications 9 1270. (https://doi.org/10.1038/s41467-01803599-w)

Park O-K \& Mayo K 1991. Transient expression of progesterone receptor messenger RNA in ovarian granulosa cells after the preovulatory luteinizing hormone surge. Molecular Endocrinology 5 967-978. (https://doi.org/10.1210/mend-5-7-967)

Ratoosh SL \& Richards JS 1985 Regulation of the content and phosphorylation of RII by cyclic adenosine 3', 5'- monophosphate, FSH and estradiol in cultured granulosa cells. Endocrinology 117 917-927. (https://doi.org/10.1210/endo-117-3-917)

Ratoosh SL, Lifka J, Hedin L, Jahnsen T \& Richards JS 1987 Hormonal regulation of the synthesis and mRNA content of the regulatory subunit of cyclic AMP-dependent protein kinase type II in cultured granulosa cells. Journal of Biological Chemistry 262 7306-7313.
Ren YA, Mullany LK, Liu Z, Herron AJ \& Wong K-K 2016. Mutant p53 promotes epithelial ovarian cancer by regulating tumor differentiation, metastasis, and responsiveness to steroid hormones. Cancer Research 76 2202-2218. (https://doi.org/10.1158/1538-7445.AM2016-SY22-02)

Richards JS 1975 Estradiol receptor content in rat granulosa cells during follicular development: modification by estradiol and gonadotropins. Endocrinology 97 1174-1184. (https://doi.org/10.1210/endo-97-5-1174)

Richards J 1978 Hormonal Control of Follicular Growth and Maturation in Mammals. New York, NY: Plennum Press.

Richards JS 1979 Hormonal control of ovarian follicular development: a 1978 perspective. Recent Progress in Hormone Research 35 343-373.

Richards JS 1980 Maturation of ovarian follicles: actions and interactions of pituitary and ovarian hormones on follicular cell differentiation. Physiological Reviews $60 \quad 51-89 . \quad$ (https://doi.org/10.1152/ physrev.1980.60.1.51)

Richards JS 1994 Hormonal control of gene expression in the ovary. Endocrine Reviews 15 725-751. (https://doi.org/10.1210/edrv-15-6-725)

Richards JS 2001 New signaling pathways for hormones and cyclic adenosine 3',5'-monophosphate action in endocrine cells. Molecular Endocrinology 15 209-218. (https://doi.org/10.1210/mend.15.2.0606)

Richards IS 2005 Ovulation: new factors that prepare the oocyte for fertilization. Molecular and Cellular Endocrinology 234 75-79. (https:// doi.org/10.1016/j.mce.2005.01.004)

Richards JS 2007 Genetics of ovulation. Seminars in Reproductive Medicine 25 235-242. (https://doi.org/10.1055/s-2007-980217)

Richards JS \& Pangas SA 2010 The ovary: basic biology and clinical implications. Journal of Clinical Investigation 120 963-972. (https://doi. org/10.1172/JCl41350)

Richards JS \& Ascoli M 2018 Endocrine, paracrine, and autocrine signaling pathways that regulate ovulation. Trends in Endocrinology and Metabolism 29 313-325. (https://doi.org/10.1016/j.tem.2018.02.012)

Richards JS, Russell DL, Ochsner S \& Espey LL 2002 Ovulation: new dimensions and new regulators of the inflammatory-like response. Annual Review of Physiology 64 69-92. (https://doi.org/10.1146/ annurev.physiol.64.081501.131029)

Richards JS, Liu Z \& Shimada M 2008 Immune-like mechanisms in ovulation. Trends in Endocrinology and Metabolism 19 191-196. (https://doi.org/10.1016/j.tem.2008.03.001)

Richards JS, Fan HY, Liu Z, Tsoi M, Laguë MN, Boyer A \& Boerboom D 2012 Either Kras activation or Pten loss similarly enhance the dominantstable CTNNB1-induced genetic program to promote granulosa cell tumor development in the ovary and testis. Oncogene 31 1504-1520. (https://doi.org/10.1038/onc.2011.341)

Richards JS, Liu Z \& Shimada M 2015 Ovulation. In Knobil and Neill's Physiology of Reproduction, 4th ed. Eds TM Plant \& AJ Zeleznik. Waltham, MA: Academic Press.

Richards JS, Ren YA, Candelaria N, Adams JE \& Rajkovic A 2018 Ovarian follicular theca cell recruitment, differentiation, and impact on fertility: 2017 update. Endocrine Reviews 39 1-20. (https://doi.org/10.1210/ er.2017-00164)

Robker RL \& Richards JS 1998 Hormone-induced proliferation and differentiation of granulosa cells: a coordinated balance of the cell cycle regulators cyclin D2 and p27Kip1. Molecular Endocrinology 12 924-940. (https://doi.org/10.1210/mend.12.7.0138)

Russell DL, Doyle KMH, Ochsner SA, Sandy JD \& Richards JS 2003a Processing and localization of ADAMTS-1 and proteolytic cleavage of versican during cumulus matrix expansion and ovulation. Journal of Biological Chemistry 278 42330-42339. (https://doi.org/10.1074/jbc. M300519200)

Russell DL, Ochsner SA, Hsieh M, Mulders S \& Richards JS 2003b Hormone-regulated expression and localization of versican in the rodent ovary. Endocrinology 144 1020-1031. (https://doi.org/10.1210/en.2002220434)

Segaloff DL, Wang H \& Richards JS 1990 Hormonal regulation of LH/ CG receptor mRNA in rat ovarian cells during follicular development and luteinization. Molecular Endocrinology 4 1856-1865. (https://doi. org/10.1210/mend-4-12-1856)

Shimada M, Hernandez-Gonzalez I, Gonzalez-Robayna I \& Richards J 2005 Cumulus-oocyte complexes (COCs) express the EGF-like factor amphiregulin that impacts not only induction of COX2 in these cells but also other genes associated with COC function. Biology of Reproduction Abstract $\# 57$. 
Shimada M, Gonzalez-Robayna I, Hernandez-Gonzalez I \& Richards JS 2006 Paracrine and autocrine regulation of EGF-like factors in cumulus oocyte complexes and granulosa cells: key role for prostaglandin synthase 2 (Ptgs2) and progesterone receptor (Pgr). Molecular Endocrinology 20 348-361. (https://doi.org/10.1210/me.2005-0317)

Simmons D, Neel B, Stevens R, Evett G \& Erikson RL 1992 Identification of an early-growth-response gene encoding a novel putative protein kinase. Molecular and Cellular Biology 12 4163-4169.

Sirois J \& Richards JS 1992 Purification and characterization of a novel, distinct isoform of prostaglandin endoperoxide synthase induced by human chorionic gonadotropin in granulosa cells of rat preovulatory follicles. Journal of Biological Chemistry 267 6382-6388.

Sirois J \& Richards JS 1993 Transcriptional regulation of the rat prostaglandin endoperoxide synthase 2 gene in granulosa cells. Evidence for a role of a cis acting C/EBP beta promoter element. Journal of Biological Chemistry 268 21931-21938.

Sirois J, Simmons DL \& Richards JS 1992 Hormonal regulation of messenger ribonucleic acid encoding a novel isoform of prostaglandin endoperoxide $\mathrm{H}$ synthase in rat preovulatory follicles. Journal of Biological Chemistry 267 11586-11592.
Sirois J, Levy LO, Simmons DL \& Richards JS 1993 Characterization and hormonal regulation of the promoter of the rat prostaglandin endoperoxide synthase 2 gene in granulosa cells. Journal of Biological Chemistry 268 12199-12206.

Wong WY \& Richards JS 1991 Evidence for two antigenically distinct molecular weight variants of prostaglandin $\mathrm{H}$ synthase in the rat ovary. Molecular Endocrinology 5 1269-1279. (https://doi.org/10.1210/mend5-9-1269)

Wong WY \& Richards JS 1992 Induction of prostaglandin H synthase in rat preovulatory follicles by gonadotropin-releasing hormone. Endocrinology 130 3512-3521. (https://doi.org/10.1210/endo.130.6.1317786)

Received 29 September 2018

First decision 6 December 2018

Revised manuscript received 11 December 2018

Accepted 18 February 2019 